\title{
Friedrich A. Hayek'in Düşünceleri ve Vergilendirme Anlayışı
}

\author{
Güngör Özcana, b, Metin Nazlığluc
}

\section{Özet}

20. yüzyılın başlarından ortalarına kadar planlamacılık ve sosyalist fikirler oldukça revaçtaydı. Politika yapıcılar belirli grupların iyiliği veya çıkarı için piyasa şartları altında ortaya çıkan sonuçların adaletsiz olduğunu iddia ederek ekonomiye müdahale edilmesi gerektiğini ileri sürmekteydiler. Ancak planlamacılar ve taraftarları, insan aklının ve bilgisinin sınırları olduğu gerçeğini göz ardı etmekteydiler. Hayek tepkileri göze alarak, planlamacıllğ ve sosyalist fikirleri eleştiren argümanlarını içeren birçok eser kaleme almıştır. $\mathrm{Bu}$ çalışmada Friedrich A. Hayek'in maddi bilgimizin sınırlılığı, zorlama ve sinırları, kurallar ve hukukun üstünlüğü ve yeniden dağıtım ile ilgi argümanları, vergilendirme ve vergi politikaları kapsamında değerlendirilmiştir. İnsan aklının ve bilgisinin sınırlarının olması, bilginin toplumda dağınık halde bulunması ve bu bilgiye politika yapıcıların sahip olamaması, güdülen vergi politikalarının belirsiz ve öngörülemez olmasına neden olmaktadır. Ayrıca artan oranlı vergilendirmenin bir yeniden dağıtım aracı olarak kullanılması, ayrımcılığa neden olmakta ve yasalar önünde eşitlik ilkesi ile çelişmektedir.
Anahtar Kelimeler

Friedrich A. Hayek

Vergilendirme

Artan oranlılık

Yeniden dağıtım

Makale Hakkında

Geliş Tarihi: 03.02.2020

Kabul Tarihi: 12.10.2020

Doi: $10.18026 /$ cbayarsos.683815

\section{Friedrich A. Hayek's Thoughts and Understanding of Taxation}

\begin{abstract}
Planning and socialist ideas were popular until the middle of 20th century. Policy makers put forward that government intervene the economy for the good or interest of certain groups as the results are unfair under the market conditions. However, planners and their supporters were not aware of the fact that human reason and knowledge had limits. Hayek drew up many works that criticize planning and socialist ideas. In this study, Hayek's writings related to limitations of factual knowledge, coercion and its limits, rules and rule of law, and redistribution are evaluated with the scope of taxation and tax policies. The fact that human reason and knowledge have limits, the information is dispersed, and the policymakers cannot possess the whole knowledge brings about tax policies to be uncertain and unpredictable. In addition, the use of progressive taxation as a means of redistribution engenders discrimination and conflicts with the principle of equality before the law.
\end{abstract}

Keywords

\author{
Friedrich A. Hayek \\ Taxation \\ Progressive Taxation \\ Redistribution
}

About Article

Received: 03.02.2020

Accepted: 12.10 .2020

Doi: 10.18026/cbayarsos.683815

a İletişim Yazarı: gungor.ozcan@cbu.edu.tr

b Dr. Öğretim Üyesi, Manisa Celal Bayar Üniversitesi, Salihli İ.İ.B.F, Maliye, ORCID: 0000-0001-5966-5582

c Arş. Gör, Manisa Celal Bayar Üniversitesi, Salihli İ.İ.B.F, Maliye, ORCID: 0000-0002-4926-298X 


\section{Giriş}

Avusturya İktisat Okulu'nun en önemli temsilcilerinden biri olan Nobel İktisat Ödülü (1974) sahibi, klasik liberalizmin 20. yüzyılda yeniden gündeme gelmesini sağlayan ve klasik liberal düşünceye katkılar sağlayan Friedrich August von Hayek (Hayek), 20. yüzyılın en etkili düşünürleri ve iktisatçıları arasındadır. F. A. Hayek kariyerine iktisat alanındaki çalışmalarıyla başlamıştır. Daha sonra siyaset felsefesi ve sosyal bilimler ile ilgili konularla ilgilenmiş ve liberal bir düzenin temellerini atmak için çaba göstermiştir. Bu kapsamda Özgürlüğün Anayasası (The Constitution of Liberty) ve üç ciltten oluşan Hukuk, Yasama ve Özgürlük (Law, Legislation and Liberty) adlı eserleri kaleme almıştır. Birçok çevre tarafından eleştirilere maruz kalacağını göze alarak, planlamacılık ve devlet müdahalesinin insanlığı köleliğe götüreceği yönünde fikirlerini yazmaktan ve paylaşmaktan geri durmamıştır. Bu çerçevede sosyalizm ve planlamacılığa yönelik eleştirilerini planlamacılığın en popüler olduğu 1940'lı yıllarda kaleme aldığı Kölelik Yolu (Road to Serfdom) adlı eserinde yayımlamıştır.

Hayek'e göre bilgi ve aklın belirli sınırları vardır ve bilgi toplumda dağınık bir şekilde bulunmaktadır. Dolayısıyla tek bir zihin tüm bilgiye sahip olamaz. Bilgisizlik soyut kuralların ortaya çıkmasını ve sosyal düzenin işleyişini sağlamaktadır. Toplumsal kurallar ve kanunlar bireylerin ve hükümetlerin faaliyetlerini sinırlandırmakta ve hükümetlerin hukukun üstünlüğüne bağlı kalmasını sağlamaktadır. İnsan aklının ve bilgisinin sınırlarının olması ve bilginin tek bir elde toplanamayışı dolayısıyla hükümetler tarafından yapılan politikaların sonuçlarının etkileri belirsiz ve öngörülemez bir hal almaktadır.

Bu çalışmanın amacı Hayek' in maddi bilgimizin sınırları, devletin sahip olduğu zorlama gücü ve sınırları, kurallar ve hukukun üstünlüğü ve yeniden dağıtım ile ilgili argümanlarını vergilendirme ve vergi politikaları kapsamında değerlendirmektir. İlk bölümde, insan aklı, bilgisi ve sınırları hakkında bilgiler verilmiş, bu sınırlılığın ortaya çıkardığı belirsizliklerden bahsedilmiştir. İkinci bölümde, Hayek'in zorlama ve sınırları hakkındaki fikirleri verilmiş, devletin zorlama gücünü kullanabileceği alanlar belirtilmiş ve bu gücü kullanırken dikkat etmesi gereken hususların altı çizilmiştir. Üçüncü bölümde, soyut kuralların ve hukukun üstünlüğü ilkesinin ortaya çıkışı ve işleyişi açıklanmıştır. Hükümetler tarafından uygulanan vergi politikalarının bu ilkeler ile olan ilişkisi irdelenmiştir. Dördüncü ve son bölümde, Hayek'in adalet anlayışından, yeniden dağıtım ile ilgi argümanlarından ve artan oranlı vergilendirmeye neden şüphe ile baktığından bahsedilmiştir.

\section{Maddi Bilgimizin Sınırları Üzerine}

Hayek, bilginin ve aklın sınırlılığını eserlerinde sıklıkla dile getirmiştir. Hayek'e göre bilginin tamamı tek bir kişide veya grupta toplanamaz. Bilgi, toplum içinde varlıklarını sürdüren bireyler arasında dağılmış bir vaziyettedir. Dolayısıyla toplumu meydana getiren her bir üye, toplumsal işleyişin dayandığı belirli olgular hakkında habersizdir. Hayek'e göre bilgi (özellikle deneyimler yoluyla elde edilmiş öznel nitelikteki bilgiler) bir bütün olarak tek bir zihinde var olamaz. Bu bilgi, farklı insanların ayrı ve çoğu zaman tutarsız ve hatta birbiri ile çelişen görüşlerinden/duyumlarından meydana gelmektedir (Hayek, 1952). 
Hayek'e göre sosyal düzenin etkili bir şekilde işleyebilmesi için ihtiyaç duyulan bilginin büyük bir kısmı, yalnızca bireylerin kendi yararlarına olabilecek gerçekleri keşfettiğinde ortaya çıkmaktadır. Bu kişilere verilmez ancak bireyler kendilerine görev edindikleri belirli hedefler üzerinde çalışırlarken bilgiyi keşfederler. Dolayısıyla bu bilgi bilimsel analizden ziyade deneyime ve uygulamalara dayanmaktadır (Hayek, 1958, s. 80). Ancak Hayek'e (1978) göre serbest piyasa şartlarının hüküm sürdüğü kendiliğinden doğan düzen içerisinde, işbölümünün de katkılarıyla, herhangi bir bireyin sahip olabileceğinden daha fazla bilgiden istifade edilebilmektedir. Söz konusu yapı içerisinde bireyin sistemin işleyişine dair tam bir bilgiye sahip olmadan hareket etmekte olması, sahip olduğumuz modern medeniyetin gelişmesine katkılar sağlamaktadır.

İnsanlar sebep-sonuç ilişkisi kurarak çevrelerine uyum sağlamaktadır. Ancak bunun yanında, insan davranışlarının çevre ile olan uyumu, insanın farkında olmadığı belirli kurallar ile şekillenmektedir. İnsan aklı çevreden bağımsız değildir. Hayek'e göre insan aklı sınıflandırma yaparak çevresine uyum sağlamaya çalışmaktadır. Bu sınıflandırma işlemini modeller kurarak yapmaktadır. Model kurma işlemi ise çevresinde var olan karmaşık yapıdaki bilgi ve duyumları seçme işlemidir; dolayısıyla bu seçim işleminin de bir sınırları vardır (Yayla, 2014, s. 77-78). İnsan aklı çevresi ile etkileşim içindedir ve bu sayede gelişmektedir. Akıl sosyal kurumların değişimini etkilediği kadar aynı zamanda kendisinin meydana getirmediği sosyal çevrenin de bir ürünüdür (Hayek, 1978).

Kartezyen Felsefe, modern felsefenin kurucusu kabul edilen Descartes' in felsefesiyle onun bu öğretisini kabul eden düşünürler için kullanılan bir anlayıştır. Bu felsefe, kişiden yola çıkarak kişiyi ve evreni anlama ve ilişki kurma çabasıdır. Descartes'e göre anlayış temelinde bilgeliği araştırır. Bilgelik insan yaşamına ilişkin bütün bilgiler olup varlı̆̆ın ilk nedenlerini irdeleyerek gerçeğe ulaşmak amacındadır (Durmaz, 2015, s. 119). Kartezyen felsefenin önemli bir çıktısı olan Kartezyen Rasyonelizmi Hayek kabullenmemiş ve önemli eleştiriler getirmiştir. Hayek bu düşünce tarzı ile ilgili eleştirilerine Hukuk, Yasama ve Özgürlük: Kurallar ve Düzen (Law, Legislation and Liberty: Rules and Order) adlı eserinde detaylıca yer vermiştir. Descartesin öğretisi Kartezyen Rasyonalizme göre akıl, açı öncüllerden mantıklı bir çıkarım yapabilen bir olgu olarak tanımlanmaktadır. Dolayısıyla rasyonel eylem yalnızca; tamamen bilinen ve ispat edilebilir gerçek tarafından tayin edilen eylem anlamına gelmektedir. Sadece bu çerçevede doğru olarak kabul edilen şey sonuçta bizi başarıya ulaştıracak ve bir kişinin tüm kazanımları söz konusu düşünce biçimi çerçevesinde eylemde bulunmasına bağlı olacaktır. Bu şekilde tasarlanmayan kurumlar ve uygulamalar ancak tesadüfen faydalı olabilir. Bu durum geleneği, örfü ve tarihi görmezden gelmektedir. Bu anlayış kurucu rasyonalizmin ayırt edici özelliklerinden biridir. Bu anlayışa göre yalnızca akıl, insanı toplumu yeniden inşa etmesine olanak sağlamaktadır. Bu rasyonalist yaklaşım çerçevesinde; ahlak, din, hukuk, dil, yazı, para ve piyasanın, biri ya da birileri tarafından önceden tasarlanarak inşa edildiği düşünülmektedir (Hayek, 1978, s. 10).

İnsan bilgisinin yapısal sınırlılıklarını fark etmeyen veya fark etmiş gibi davranan kurucu rasyonalistlerin sahip olduğu bu düşünce onları sosyal bilimlerde "bilimsicilik" anlayışına doğru varmalarına sebep olmuştur (Akınc1, 2017, s. 77). Toplumumuzu anlamaya ve biçimlendirmeye yönelik fikirlere sahip kurucu rasyonalistlerin yanıldığı nokta, sosyal düzen içindeki bütün verileri incelenebilir bir bütün olarak toplamaya kapasitemizin olduğunu 
zannetmeleridir. Bu argüman kapsamında, yani sosyal düzene ait tüm verilere sahip olarak (ki bu durum mümkün değildir), yapılan planlar insanlara mükemmel görünebilir. Ancak bu planların kusursuz görünmesinin sebebi, plancıların bilmediği tüm gerçekleri ihmal edişine bağlıdır (Hayek, 1978, s. 14-15).

Hayek' göre sahip olduğumuz kurumlar ve uygulamalar, gerçekte ne icat edilmiş olan ne de böyle bir amaçla tasarlanan adetlerin, alışkanlıkların ve tecrübelerin bir ürünüdür. İçinde yaşadığımız toplumda, kendi durumumuzu başarılı şekilde idare edebilir ve davranışlarımızı hedeflerine ulaştırmak için gerekli olan şansa sahip olabiliriz çünkü diğer insanların da amacını çok defa bilmediğimiz ve fiili varlığının çoğunlukla farkında olmadığımız kurallar tarafından sınırlanması dolayısıyla böyle bir toplumda hayatımızı idame ettirebiliriz (Hayek, 1978, s. 11). Ayrıca Hayek (1978), insanların en az amaç peşinde koşan özelliklerinin yanında kural izleyici özelliklerinin olduğunu da vurgulamaktadır.

Hayek' in bilgi anlayışı kural yöntemlidir ve aklı soyut kurallar çerçevesinde tanımlamaktadır. $\mathrm{Bu}$ soyut kurallar, belirli insan eylemlerini bir birleşik olarak belirleyen kurallardır. Soyut kuralların çoğunu kelimeler ile ifade etmemiz imkansızdır. Hayek'e göre bilgi yalnızca bilinçli eylemler sonucunda ortaya çıkmamaktadır. Bilgi ayrıca bireylerin ve toplumların sahip olduğu geleneklerde ortaya çıkmaktadır (Yayla, 2014, s. 78).

Hayek'in sıklıkla üzerinde durduğu mesele, toplumsal hayatta ayrı ayrı insanların davranışlarını tayin eden olguların çoğunluğu hakkında bilgisiz olması ve bu durumun hiçbir şekilde giderilemeyecek olmasıdır. Bununla birlikte, toplumsal süreçleri belirleyen olgular hakkındaki bilgisizliğimiz sosyal kurumların da biçimlerini almasını sağlamaktadır. İnsanların faaliyetlerini sürdürdüğü toplumsal yapı, sürekli biçimde kendisini bütün olarak hiç kimse tarafından bilinmeyen olgulara veya gerçeklere adapte etmekte ve işleyişini bu şekilde devam ettirebilmektedir. Bu süreç en belirgin şekilde ekonomi alanında karşımıza çıkmaktadır. Sosyalist bir ekonominin bulunmadığı bir toplumda iktisadi hayatı, bireyler ve firmalar arasındaki milyonlarca ilişki ve etkileşim şekillendirmektedir (Hayek, 1978).

İlkel küçük toplumlarda, toplum üyeleri arasındaki iş birliği herkes tarafından bilinebilen belirli şartlara dayanmaktadır. Dolayısıyla insanlar günlük yaşantılarında karşılaşacakları somut olaylar neredeyse hepsi için aynı olacaktır çünkü insanların haberdar oldukları olaylar ve hedefler aşağı yukarı aynıdır. Ancak içinde bulunduğumuz Büyük veya Açık Toplum'da durum çok daha farklıdır. Hayek'e göre içinde yaşadığımız gelişmiş uygarlığın en belirgin özelliği, herkesin sahip olabileceğinden daha fazla bilginin kullanılabilmesidir. Söz konusu uygarlık; işleyişini herhangi bir bilginin ortaya çıkmasını sağlayanların kendisi tarafından bilinmeyen tutarlı bir yapı içinde hareket etmesine borçlu olmasıdır. Buna ek olarak, bireysel bilginin miktarı üzerindeki sınırlılığı aşmakta rol oynayan faktör, bilgisizliğin fethedilmesidir. Sonuç olarak, bir birey her ne kadar bilgisiz olsa bile içinde bulunduğu uygar medeniyetten muazzam şekilde faydalanabilir (Hayek, 1978, s. 14).

Hayek'e göre bilgisiz insanlar, toplum halinde yaşadığımız için bilgiden mahrum kalmamaktadır. Bireyler ihtiyaç duydukları bilginin mahiyetini ve boyutunu bilmese bile, kurallara uygun eylemde bulunursa, gelenekler ve adil davranış kuralları (rules of just conduct) dolayısıyla oluşmuş bilgiler ona rehberlik edecektir. Hayek'e göre bireysel refah ve 
toplumsal gelişimin temelinde bireylerin sahip olduklarından daha fazla bilgiyi kullanabilmesi yatmaktadir (Yayla, 2014, s. 81).

Özetlemek gerekirse, Hayek'in bilgi teorisi anti-rasyonalisttir. Hayek kurucu rasyonalistlerin akla yükledikleri fonksiyonları eleştirmekte ve insan aklının her şeyi gerçekleştirmeye muktedir olmadığının altını çizmektedir. İnsan çevresine uyum sağlarken bireylerin ve toplumların sahip olduğu geleneklerden de etkilenmektedir. Sosyal kurumların ortaya çıkmasında akıl tek belirleyici değildir. Aklın yanı sıra, geleneklerin, deneyimlerin ve bunların içinde yer alan bilgiler ve kuralların rolü de oldukça önemlidir (Yayla, 2014).

Toplumda dağınık halde bulunan ve tek bir akla verilemeyen bilgi, piyasaya dayalı bir sosyal düzen içinde (Hayek bu durumu "catallaxy" olarak tanımlamaktadır) bireylerin faaliyetleri ile ilgili bilgi edinmeleri ve edindikleri bilgileri kullanabilmeleri için fırsatlar ve teşvikler sağlamaktadır. Ancak bilginin kullanımı üzerindeki sınırlılık nedeniyle piyasa müdahalesinde bulunan hükümetler, müdahalelerinin sonuçları ile ilgili belirsizliklerle karşı karşıya kalacaklardır. Hayek belirli grupların ve bireylerin çıkarlarına hizmet etmek ve belirli toplumsal amaçları gerçekleştirmek amacıyla devlet iktidarının kullanılmasına karşı çıkmaktadır. Ekonomi bilimi piyasaya dayalı sosyal düzenin işleyişini ve genel doğasını anlamamızı sağlayabilir. Ancak hükümetin piyasaya yapmış olmuş müdahaleler sonucu ortaya çıkabilecek sonuçları öngörebilmemizi her zaman sağlayamaz çünkü bu durumla ilgili tüm bilgiye sahip olamayız. Dolayısıyla ekonomi, sahip olmadığı bir somut bir durum hakkında ayrıntılı bilgi sağlayamaz (Hayek, 1978).

Piyasa müdahaleleri sonucu ortaya çıkan belirsizlik kapsamında değerlendirme yaptığımızda, vergilendirme politikaları da belirsizlikler içermektedir. Çünkü bu politikaların muhtemel sonuçları milyonlarca insanın öngörülemez ve birbirinden bağımsız davranışına bağlıdır. Örneğin kamu maliyesi alanında vergi yükünün kimlerin üsteleneceğini ya da hangi sınıflar arasında dağılması gerektiği yönünde bir dizi tartışma bulunmaktadır. Hayek'e göre alıcı ve satıcıların zihinlerinde var olan bilgiye sahip olmamızın imkansızlığından dolayı vergi politikaları aracılığıyla ortaya çıkabilecek etkileri önceden kestirebilmemiz imkansızdır. Hayek toplumsal düzen içerisinde, vergi politikaları aracılığıyla belirli ekonomik davranışları teşvik etmenin veya belirli grupları cezalandırmanın imkansızlığını vurgulamaktadır. Vergi politikasının insan davranışları üzerindeki etkisi bizim hiçbir zaman sahip olamayacağımız büyüklükte bir bilgiye bağlı olduğu için, politikanın etkileri kaçınılmaz şekilde ya belirsiz olacak ya da esasen hedeflenen şeyin tam tersi bir sonuç ortaya çıkaracaktır (Spicer, 1995, s. 105).

\section{Zorlama ve Sınırları Üzerine}

Günümüzde verginin en önemli özelliklerinden biri gerçek veya tüzel kişilerden zorlama ile alınmasıdır. Devlet sunduğu kamusal mal ve hizmetlerin finansmanı için, sahip olduğu egemenlik gücüne dayanarak hukuki cebir altında vergi toplamaktadır. Verginin en önemli özelliği ise hukuki bir zorlamaya dayanmasıdır. Hayek Özgürlüğün Anayasası (The Constitution of Liberty) adlı eserinde zorlama üzerinde durmakta ve zorlamanın sinırlarının neler olması gerektiğini vurgulamaktadır. 
Hayek'e göre zorlama, bir başkasının hizmetine sunabilmek için bir insanın eylemlerinin bizzat kendisinin değil başka birinin yararına yönlendirilmesidir. Ancak burada zorlanmaya tabi olan kişi hiç seçimde bulunmuyor değildir. Burada bir seçim vardır ancak seçimde bulunan kişinin zihni başka birinin bir aracı haline gelmektedir. Zorlamaya maruz kalan kişi seçimde bulunsa bile, zorlayıcının isteği doğrultusunda tercihte bulunmak durumunda kalmaktadır. Zorlamaya maruz kalan kişinin sahip olduğu kapasitenin tamamını kullanması için önünde bir engel yoktur ancak sahip olduğu bilgi birikimi ve yeteneklerini kendi amaçları için kullanmaktan mahrum bırakılmaktadır. Bu sebeple zorlama; kişiyi sahip olduğu zihinsel güçleri optimum düzeyde kullanmaktan alıkoyduğu ve dolayısıyla kişinin maksimum toplumsal katkıyı yapmasını engellediği için kötü olarak nitelendirilmektedir. Hayek'in altını çizdiği noktalardan biri, iktidar (power) ve zorlama (coerce) kavramlarının birbirine karıştırılmaması gerektiğidir. Kötü olarak nitelendirilen, zarar verme tehdidi ile insanları başka biri için hizmet etmeye yönlendiren zorlama kuvvetidir. Diğer taraftan, insanları kendi rızaları ile kendilerinin belirlemiş olduğu amaçlar doğrultusunda gönüllü olarak meydana getirmiş oldukları herhangi bir büyük teşebbüsün idarecisi tarafından yönetilmesi adına kullanılan iktidarda ise bir kötülük bulunmamaktadır (Hayek, 1960, s. 133-135).

Zorun yadsınması ve engellenmesi anlayışına ilişkin kurulan Hayek'in benimsediği negatif özgürlük anlayışı kişilere serbestçe ve iradelerine ilişkin hareket edebilecekleri bir özel alan sağlar. Bu alanda diğer kişilerin tercihleri ve istekleri bilinçli olarak hariçte bıraktırılır. Kişi, kişi olmanın ve özgürlügünü kullanmanın getirdiği sorumluluğunun da bilincinde olarak negatif özgürlük kapsamının dahilinde kalacak şekilde, diğer kişilerden gelecek kısıtlamaların, keyfiliğin ve zorun uzağında bulundurulur (Kurt, 2006, s. 203). Hayek'e göre devletin zorlama kuvvetine başvurmasının en önemli gerekçelerinden biri vergilendirmedir. Devlet üstlenmiş olduğu temel faaliyetleri (engellilerin bakımı, yollar ve posta hizmetinin sağlanması gibi) finanse edebilmek için zorlama kuvvetine başvurmak durumundadır. Ancak burada belirtilmelidir ki devletin sağlamış olduğu hizmetler zorlayıcı nitelik taşımamaktadır. Devlet yalnızca zorlayıcı niteliğe sahip olmayan hizmetlerin finansmanı için zorlama kuvvetine başvurmaktadır. Piyasaya dayalı bir şekilde işleyiş gösteren ve adil davranış kuralları ve gelenekler tarafından şekillendirilen kendiliğinden doğan düzen içinde devletin de sahip olduğu birtakım görevler vardır. Devlet bu görevlerini yerine getirebilmek adına zorlama gücüne başvurmaktadır. Ancak devlet bu gücünü kullanırken söz konusu toplumsal yapının işleyişini sekteye uğratmamalıdır. Devlet zorlama gücünü kullanırken, bireylerin mülkiyet haklarını, yasalar önünde eşitlik ilkesini ve adil davranış kurallarını gözetmelidir (Hayek, 1960).

\section{Kurallar ve Hukukun Üstünlüğü Üzerine}

Hayek'in çalışmalarının yoğunlaştığı alanlardan diğeri; kuralların toplumsal düzendeki yeridir. Hayek'e göre sınırlı düzeydeki bilgimiz ve dolayısıyla ortaya çıkan belirsizlik, insanlar arasındaki etkileşimi düzenleyen ve insan faaliyetlerinin diğer insanlar üzerinde kötü etkiler bırakmasını sınırlayan bir kurallar sisteminin ortaya çıkmasına neden olmaktadır. Özgür bir toplumda yaşayan tüm bireylerin ve hatta hükümetlerin davranışları, adil davranış kuralları tarafından sınırlandırılmalıdır. Adil davranış kuralları, Açık Toplum'u mümkün kılan amaçtan bağımsız ve kendiliğinden doğan düzene katkı sağlayan kuralları tanımlamak için kullanılmaktadır (Hayek, 1998, s. 31). Söz konusu davranış kuralları, insan aklının 
sınırlılığ1 neticesinde ortaya çıkan belirsizlikle mücadele edilebilmesi için evrimsel bir fonksiyon yüklenerek toplumsal düzenin işleyişine katkılar sağlamaktadır (Hayek, 1978). Ayrıca, "eylemlerimizi yöneten davranış kurallarının ve bu düzenlilik dolayısıyla ortaya çıan kurumların çoğunun, herhangi bir kimsenin düzenine dahil olan tüm gerçeklerin tamamını bilinçli olarak dikkate almasının imkansızlığına olan uyumu', Hayek'in en önemli argümanlarından biridir (Hayek, 1978, s. 13). Hayek'e (1978) göre adil davranış kurallarının amac1, farklı bireylerin birbirlerine müdahale etmedeki eylemlerini mümkün olduğunca önlemektir. Adil davranış kuralları, bireyler için bir eylem/hareket alanı tanımlamaktadır (Spicer, 1995).

Hayek (1960) ayrıca kuralların muayyen (bilinmesi) ve kesin olması gerektiğinin altına sıklıkla çizmektedir. Ayrıca hükümetin faaliyet alanın kurallarla sınırlanması gerektiğini ve hükümetin dayattığı kurallardaki değişikliklerin özel sektör üzerinde belirsizliklere neden olmaması gerektiğini vurgulamaktadır. Devletin bireylerin eylemlerini belirli amaca yöneltmek için kullanması durumunda; devlet müdahalesinin muhtemel sonuçlarını öngörmede ve gereken tüm bilgiye haiz olmada devletin başarısız olacağını ifade etmektedir (Hayek, 2007, s. 76). Dolayısıyla zorlayıcı güç kullanma yetkisine sahip kurumların takdir yetkilerinin en aza indirilmesi gerekmektedir. Kanunlar, vatandaşların eylemde bulundukları alanlara bir kısıtlama getirirken, aynı zamanda hükümetlerin hukukun üstünlüğü ilkesine bağlı kalmasını sağlayarak bireysel faaliyetlere müdahale edilmesini engellemektedir. Kuralların önceden biliniyor olması, bireylerin kendi menfaatlerini diledikleri gibi takip etmelerine imkân sağlamaktadır (Hayek, 2007, s. 112-113). Hayek'e (1960) göre ayrıca; eğer bireyler vergi ile ilgili yerine getireceği ödevlerinden haberdar olursa, hayatları ile alakadar planlarını daha kolay takip edebilirler. Bireylerin hayatına devletin kaçınılmaz zorlayıcı müdahalesinin yanında bir de tahmin edilemezlik eklenirse, bu durum bireylerin hayatlarını sağlıklı bir şekilde idame ettirmesini engelleyebilir (Hayek, 1960, s. 143). Hayek' in bu fikirleri, Adam Smith'in (2006) vergileme ilkelerinden biri olan belirlilik/kesinlik ilkesinin tekrardan hatırlanması ve öneminin vurgulanması açısından önemlidir (Smith, 2006).

Hayek'e göre vergilendirme sistemleri genellikle kamu harcamaları neticesinde ortaya çıkan mali yükün mümkün derecede gizlenmesi gayreti ile şekillenmiştir. Kamu maliyesi, devlet faaliyetleri sonucunda ortaya çıkan mali yükü taşıyacak olanların farkına varmalarını engellemek amacıyla tasarlanmıştır. Vergi sistemlerinin sahip olduğu karmaşık yapı, vatandaşları kendi istekleri doğrultusunda razı geleceklerinden daha fazlasını vermeye ikna etme yönündeki gayretlerin bir sonucu olarak ortaya çıkmıştır (Hayek, 1981, s. 126-127). Vergi sistemlerinin karmaşık ve anlaşılmaz bir yapıya sahip olması, adil davranış kurallarının açık ve kesin olması ilkelerinin zedelenmesi anlamına gelmektedir. Gelir düzeyi daha düşük olan bireylerin durumlarının iyileştirilmesi için (yani onların çıkarı için) artan oranlı vergilendirmenin kullanılması birçok liberal çevrede de kabul görmüş ve bu yöndeki politikalar desteklenmiştir. Ancak Hayek (1990) ise gelir düzeyi daha yüksek veya daha varlıklı bireylerin daha fazla vergilendirilmesinin bir yeniden dağıtım aracı olarak kullanılmasının, yasa önünde eşitlik ilkesi ile çeliştiğini ifade etmektedir. Bu görüş özellikle 19. Yüzyıl liberalleri tarafından benimsenmiş ve sıkça vurgulanmıştır (Hayek, 1990, s. 142). Hayek, kamu sektörünün ve faaliyetlerinin meşruiyetini açıklarken üç nokta üzerinde durmaktadır. Bunlar; hükümetin sahip olduğu zorlama gücünün kuralları ile sinırlanıp 
sınırlandırılmadığı, dayattığı ya da yürürlüğe koyduğu kuralların bireyler ya da vatandaşlar arasında eşit bir şekilde uygulanıp uygulanmadığ 1 ve son olarak sosyal düzenin işleyişine bir katkı sağlayıp sağlamadığıdır (Butler, 2001, s. 151-152).

Hayek'in önemle üzerinde durduğu ilkelerden bir diğeri "hukukun üstünlüğü" ilkesidir. Hayek'e (1944) göre özgür bir ülke ile keyfi yönetimlerin mevcut olduğu bir ülkeyi birbirinden ayıran en önemli kıstas hukukun üstünlüğü ilkesine gösterilen önemdir. Bu ilke devletin üstlenmiş olduğu görev ve sorumlulukları yerine getirirken önceden belirlenmiş kanunlara ve kurallara bağlı olması gerektiğini ifade etmektedir. Hukukun üstünlüğü ilkesi ile yasama organı da dahil olarak üzere politik karar alma sürecinde rol oynayan tüm aktörlerin yetki alanları sınırlandırılmaktadır. Dolayısıyla hukukun üstünlüğ̈̈ ilkesi, iktidar yetkisinin belirli ellerde toplanmasını engellemekte ve devletin ve diğer aktörlerin gücünü kanunlar çerçevesinde sınırlandırmaktadır (Hayek, 1960).

Hayek'e göre hukukun üstünlügüne uygun kuralların aşağıda belirtilen belli başlı özellikleri vardır (Yayla, 2014, s. 45-49):

a. Kanunlar belirli kişi ve gruplar arasında ayrımcılığa neden olmamalıdır. Adil davranış kuralları veya kanunlar özgürlüğü korumalı ve insanların kendi özgürlük alanı içinde dilediği gibi hayatını yaşamasına izin vermelidir.

b. Kuralların ve kanunların öngörülebilir ve tarafsız olması hukukun üstünlüğü ilkesinin tesis edilmesi açısından önemlidir.

c. Devletin ekonomik hayattaki müdahaleci uygulamaları hukukun üstünlüğü ilkesi ile ters düşmektedir.

Hayek artan oranlı vergilendirmeye ve arkasında yatan motivasyonlara şüphe ile yaklaşmaktadır. Hayek'in bu şüpheli yaklaşımının temelinde vatandaşlara yasalar önünde eşit muamele eden davranış kurallarının önemini vurgulaması yatmaktadır (Spicer, 1995, s. 108). Artan oranlı vergilerin direkt olarak ayrımcilığa zemin hazırladığını ve keyfilik barındırdığını ifade etmektedir. Hayek'e göre vergilendirme geniş tabana yayılmalı ve ayrımcılık içermemelidir. Ayrıca vergi politikası yapıcıları keyfiliği caydırmak istiyorlarsa, yatay eşitlik ve tarafsızlık takip etmeleri gerektikleri normlardır (Hayek, 1960, s. 314).

Hayek'e göre yeniden dağıtımcı hükümet politikaları hukukun üstünlüğü ilkesi ile çelişmektedir. Çünkü sosyal adaletin tesis edilmesi adına uygulanan politikalar ya da yürürlüğe giren kanunlar; öngörülebilirlik, genellik ve tarafsızlık ilkeleri ile ters düşmektedir. Nedenini açıklamak gerekirse, sosyal adaletin dağıtımcısı konumunda devlet, adaleti tesis edebilmek adına vatandaşları arasında değer yargılarına bağlı olarak uygulama yapmak durumunda kalacaktır (Yayla, Özgürlük Yolu: Hayek'in Sosyal Teorisi, 2014, s. 48-49). Bu uygulama ya da kararların dağıtımcı rolünü üstelenenlerin sübjektif değer yargılarını içermesi, ortaya bir öngörülemezlik veya belirsizlik çıkarmaktadır. Dolayısıyla hukukun üstünlüğü ve vatandaşların yasalar önünde eşit muamele görme ilkesi zedelenmektedir.

\section{Yeniden Dağıtım Üzerine}

Hayek'in yeniden dağıtım ile ilgili görüşlerine yer vermeden önce, Hayek'in adalet ve sosyal adalet ile ilgili görüşlerine yer vermek isabetli olacaktır. Hayek'in adalet teorisi, 'prosedürel adalet" içerisinde yer almaktadır. Prosedürel adalet, "hukukun üstünlüğü" veya "yasalar 
önünde eşitlik" prensipleri ile yakından ilgilidir. Prosedürel adalette önemli olan, kuralların herkese eşit uygulanmasıdır. Söz konusu düşünce tarzı, klasik liberalizmin temel ilkelerinden biri olan negatif özgürlüğün yansımasıdır. Negatif özgürlüğün mevcut olduğu durumlarda, devletin sosyal amaçlı sorumluluklarının olmadığı ifade edilmektedir (Erdoğan, 1993, s. 109). Hayek' in sahip olduğu prosedürel adalet teorisinin temelinde metodolojik bireycilik anlayışı bulunmaktadır. Metodolojik bireycilik, bireysel değerleri ve bireyin davranışlarının gücünü vurgulamakta; toplumu ve diğer toplumsal kurumları anlayabilmek için bireylere veya bireysel davranışlara önem vermektedir. (Aktaş, 2018, s. 231). Hayek'e göre adalet bireysel davranışın bir özelliğidir. Adil veya gayri adil olmak bireylere has kavramlardır. Dolayısıyla Hayek, "adalet anlamlı bir şekilde, ancak insan eylemine atfedilebilir; o eylemin birisi tarafından bilinçli olarak meydana getirilip getirilmediğine bakmaksızın herhangi bir ilişkiler durumuna değil" şeklindeki ifadesiyle adalet kavramının bireysel bir özellik taşıdığının altını çizmektedir (Hayek, 1966).

Hayek prosedürel adalet anlayışına sahip olduğu için, fikirleri düzeltici adalette karşılığını bulmaktadır. Düzeltici adalet anlayışı, maddi eşitlikten ziyade bireylerin yasalar önündeki eşitliğini temel almaktadır. Bu anlayış, maddi eşitliği tesis etmeye yönelik uygulamalara karşı çıkmaktadır. Düzeltici adalet, hukuki işlemlerin yapıldığı süreçte taraflar arasındaki dengenin bozulması durumunda dengenin yeniden tesis edilmesi için gerekenlerin yapılmasını emretmektedir. Buna karşılık, hukuksal işlemlerin usulüne uygun bir şekilde yapılması durumunda ortaya çıkan sonuçların sosyal amaçlarla değiştirilmesinin talep edilmesi, düzeltici adalet ile çelişmektedir. Düzeltici adalet, hukuksal açıdan bir usulsüzlügün olmadığı ve piyasanın soyut kurallarına uygun bir şekilde hukuksal işlemlerin yapıldığ 1 durumda ortaya çıkan sonuçların, bir tarafı ekonomik açıdan kötü duruma düşürse bile, bir adalet sorunu ortaya çıkarmadığını ileri sürmektedir (Aktaş, 2018, s. 244-245).

Bir kendiliğinden düzen içinde bir bireyin konumu, grup içindeki birçok başka diğer bireyin eylemlerinden etkilenmektedir. Bu sebeple birçok kişinin eylemlerinin belirli bir kişi için spesifik bir sonuç meydana getireceği yönündeki iddiaları geçerli değildir. Bireylerin kendiliğinden düzen içindeki konumları, başka bir kişinin davranışı ve ortak uyumlu davranış gibi faktörlerden etkilenebilmektedir. Dolayısıyla, Hayek'e göre, kendiliğinden doğan düzen içinde bir kimsenin konumunun ne olacağını belirleyebilecek bir kural mevcut olamaz. Ayrıca sadece insanın bilinçli bir şekilde meydana getirilmiş durumları adil ve gayri adil olarak değerlendirilebileceği için, bir kendiliğinden düzene ait durumlar adil veya gayri adil olamaz. Örneğin, A kişisinin B kişine nazaran daha az şeye sahip olması, bir kimsenin bilinçli olarak gerçekleştirmiş olduğu bir eylemin sonucu değilse, bu durumu adil veya gayri adil olarak değerlendirmek doğru olmayacaktır (Hayek, 1998, s. 33-34). Sosyal adaleti tesis etmek adına bir yardımlaşma veya dayanışmanın zorlama ile bireylere dayatılması, klasik liberal bireyci anlayışa sahip düşünür tarafından reddedilmektedir. Metodolojik bireycilik açısından değerlendirme yapıldığında Hayek, sosyal açıdan bir adaletsiz durumun ortaya çıkmadığını ifade etmektedir. Özetle Hayek' in adalet anlayışının özellikleri şunlardır (Hayek, 1998):

a. Prosedürel adalete dayanmaktadır.

b. Metodolojik bireycilik prensibine dayandığı için, sadece bireylerin davranışları adalet açısından değerlendirilebilir. 
c. Hayek; A. Smith ve I. Kant'tan etkilendiği için, adalet kavramı ile bireysel davranışlar arasında güçlü bir bağ olduğunu vurgulamaktadır (Yayla, 1991, s. 102).

d. Yasa önünde eşitlik ve hukukun üstünlügü ilkesi ile yakından ilişkilidir.

e. Subjektif değer teorisi Hayek'in adalet anlayışını şekillendirmektedir.

f. Hayek dağıtıcı adalet yani sosyal adalet anlayışına şüphe ile yaklaşmaktadır.

g. Hayek'in kuralları negatif karakterli olduğu için, adalet belirli sonuçları garanti etmemektedir.

h. Hayek adalet teorisini kendiliğinden doğan düzen anlayışına dayandırmaktadır.

i. Hukuki işlemler önceden belirlenmiş olan soyut kurallar kapsamında gerçekleştiriliyorsa, söz konusu hukuki işlemler sonucu ortaya çıkan durumu adalet açısından irdelenemez. Çünkü taraflardan biri için ortaya olumsuz bir durumun çıkması, hukuki işlemi adalet açısından değersiz kılmamaktadır.

Hayek sosyal adalet kavramının kötüye kullanıldığını ifade etmekte ve bu kötüye kullanımın, hukuku bireysel özgürlügün teminatı yapmış anlayışı yerle bir etme tehlikesine maruz bıraktığını vurgulamaktadır. Kimi insanlar tarafından piyasanın kendiliğinden düzeni içinde meydana gelen sonuçlar, sanki bir bilinçli eylem dolayısıyla ortaya çıkıyormuş ve meydana gelen yarar ile zararların iradi eylemler tarafından belirleniyormuş gibi algılanmıştır. Sosyal adalet kavramının ortaya çıkmasında ayrıca sosyalizme ait birtakım kavramlar insanların zihinlerinde yer etmiştir. Zihinlerde yer eden söz konusu kavramlar, sosyal ve iktisadi hayatın daha mütevazı bir biçimde düzenlenebileceğine inananların artmasına neden olmuştur. Dolayısıyla birçok politika yapıcı, planlamayı savunmamalarına rağmen sosyal sorumluluk, sosyal hakları gibi olguları geliştirmek için devlet müdahalesine sıcak bakmaya başlamışlardır (Butler, 2001, s. 119-120).

Hayek'e göre sosyal adalete olan inanç, özgürlük temeline dayanan uygarlığımızın değerlerine yönelmiş en önemli tehditlerden biridir. Sosyal adaleti tesis etmek adına insanlar, devlete sayısız yekiler vermekte ve bireysel özgürlüğün tahrip edilmesine kap1 aralamaktadırlar. Bireyler ve gruplar mevcut konumlarının giderek devlete daha da bağımlı hale geldiklerini farkına vardıkça, devletin dağıtıcı adaleti sağlama yönünde atacağı adımlara olan taleplerini arttıracaktır. Dolayısıyla devletin de bu talep artışı karşısında daha da fazla birey ve grupları kontrol etmesi gerekecektir. Hayek, bu yöndeki inanç ve israrın devam etmesi durumunda totaliter bir sisteme yaklaşılacağını ifade etmektedir. Özgür bireylerden meydana gelen bir toplumda, mevcut maddi malların dağılımına yönelik adaletsizlik duygusu; insanların sürekli olarak hayatın kendilerine kötü davrandığı yönündeki algısından ve ödül elde etmenin bir çabaya endekslendiği durumda, hepimizde meydana gelen hak etme duygusu ve çabalarımızın karşılığını alma duygusundan kaynaklanmaktadır. Kendiliğin doğan düzenin mevcut olduğu bir toplumda esasen kimin adaletsiz olduğu sorusunun cevab1 bulunamayacaktır. Hayek'e göre (Hayek, 1998, s. 69),

"Her bir kişinin kendi bilgisini kendi amaçları için kullanmasına izin verilen bir sistemde, "sosyal adalet" kavramı zorunlu olarak boş ve anlamsızdır; çünkü bu sistem içinde hiçbir kimsesin iradesi, farklı insanlarm nispi gelirlerini belirleyemez veya bu sonuçların kısmen tesadüfe bağhı olmalarını önleyemez."

Sosyal adalet kavramı "dağıtıcı adalet" olarak da kullanılmaktadır. Dağıtıcı adalet kavramı, aslında amaçlanan şey hakkında bilgi vermekte ve ayrıca kendiliğinden düzen içinde piyasa 
sonuçlarına neden uygulanamayacağı hakkında bizi haberdar etmektedir. Dağıtım ancak bir dağıtıcının olduğu yerde gerçekleşebilir. Kendiliğinden düzende; piyasa koşulları altında, bireyler kendileri ile ilgili durumlarda adil veya gayri adil davranışlar sergileyebilirler ancak birbirleriyle etkileşim halinde olan ayrı kişiler için ortaya çıkan sonuçlar ne tasarlanabilir ne de öngörülebilir. Dolayısıyla ortaya çıkan sonuçları adil veya gayri adil olarak değerlendirmek anlamsızlaşacaktır. Piyasa düzeninde aralarında mal ve hizmet sağlama yönünde çeşitli ilişkilerin bulunduğu bireylerin davranışları için hiçbir makul kural, anlamlı, haksız veya gayri adil olarak tanımlanabilecek bir dağıtım gerçekleştiremeyecektir (Hayek, 1979, s. 4).

Hayek (1960) yeniden dağıtım için artan oranlı vergilerin kullanılmasının hemen her yerde kabul edilir hale geldiğini belirtmektedir. Ancak yine de bu durumu tartışmaktan kaçınmamıştır. Hatta Özgürlüğün Anayasası (The Constitution of Liberty) eserine yeniden dağıtım ve vergilendirme ile ilgili bölümü eklerken tereddütler yaşamış ancak çekeceği tüm tepkilere rağmen artan oranlı vergilendirme ile ilgili eleştirilerini açıklamaktan geri durmamıştır. Öncelikle Hayek'e göre hangi durumlarda artan vergilendirmenin kabul edilebilir olduğunu açıklamak faydalı olacaktır. Kişisel vergiler ve özellikle gelir vergisi, dolaylı vergilerin görece daha düşük gelir düzeyindeki grupların üzerinde daha ağır bir büyük bırakması durumunda, meydana gelen dengesizlikleri gidermek için kullanılabilir. Ancak artan oranlı vergilendirme belirli vergiler için geçerli olmalı, vergi sisteminin tamamina uygulanmamalıdır (Hayek, 1960).

Artan oranlı vergilendirme yeniden dağıtımı gerçekleştirmek adına kullanılan araçlardan biridir. Hayek, artan oranlı vergilendirmenin sakıncalarından bahsetmeden önce, bir sabit oranlı vergilendirme sistemi ile sağlıklı ve istenebilir bir yeniden dağıtımın gerçekleştirilip gerçekleştirilemeyeceği sorusuna odaklanmaktadır. Hayek'e göre sabit oranlı bir vergilendirme ile yeniden dağıtımı gerçekleştirebilmek için yapılacak şey toplanan gelirin bir kısmını belirli bir sınıfın yararlanacağı hizmetleri sunmak için kullanmak veya söz konusu sınıfı doğrudan sübvanse etmektir. Artan oranlı vergilendirmenin ortaya çıkışında rol oynayan esas fikirlerden biri fedakarlıkta eşitliği sağlamaktır. 19. yüzyılın sonlarına doğru da artan oranlı vergilendirmeyi savunanlar, amaçlarının yeniden dağıtım değil fedakarlıkta eşitliği sağlamak olduğunu belirtmiş ve ılımlı bir artan oranın benimseneceğini ileri sürmüşlerdir. Hayek (1960), artan oranlı vergilendirmenin bir kez benimsenmesinden sonra artan oranın öngörülebilir bir sınırın ötesinde bir hal alacağını ifade etmektedir. Artan oranlı vergilendirmenin ilk uygulamalarından biri olan Prusya'da 1891 yılında \%0,67'den \%4'e yükselen artan oranlı gelir vergisi uygulaması hayata geçirilmiştir. Rudolf von Geist (Alman hukukçu ve politikacı) bu uygulamanın mülkiyet haklarını ihlal edeceğini ve yasalar önünde eşitlik ilkesi ile çelişeceğini ileri sürerek Meclis'te bir protesto gerçekleştirmiştir. Almanya'dan yaklaşık 20-30 yıl sonra Amerika Birleşik Devletleri ve İngiltere de artan oranlı vergilendirme yoluna gitmiş ve başlangıçta \%7-8 olarak belirlenen oranlar 30 yıl içinde \%90'lara kadar varmıştır. Artan oranlı vergilendirmenin tek gerekçesi gelir dağılımında adaletin iyileştirilmesidir. Ancak Hayek'e göre bu gerekçe yalnızca çoğunluk adına belirlenmiş bir dağıtım kalıbı getirme teşebbüsü olarak değerlendirilmesi dışında hiçbir bilimsel dayanağ bulunmamaktadır (Hayek, 1960, s. 310). 
Hayek'e (1960) göre artan oranlı vergilendirme, farklı kişilerin nispi vergi yükünün ne olması gerektiği hakkında bir ilke sunmamaktadır. Hayek artan oranlılığı zengin gruplara karşı bir ayrımcılık olarak değerlendirmekte ve söz konusu ayrımcılı̆̆ın derecesinin sınırlandırılması noktasında hiçbir ölçünün olmadığını ifade etmektedir. Artan oranlılığın kabul edilemez düzeylere ve cezalandırıcı oranlara yükselmesinin önünde hiçbir engel yoktur. Hayek artan oranlılığı ayrımcılığa açık bir davet olarak değerlendirmektedir. Artan oranlılık, çoğunluğu azınlığa karşı ayrımcılığa itmekte ve adalet ilkesinin keyfiliğin bir aracı olmasına neden olmaktadır. Dolayısıyla bir çoğunluğun sırf çoğunluk diye kendine uygulamadığı bir kuralı azınlığa uygulama hakkının olması demokrasinin ihlal edilmesi anlamına gelmektedir. Hayek'e göre artan oranlılık yeniden dağıtım kapsamında düşük gelirli kesimlere yardım etmek yerine, işçi sınıfına ve orta sınıfın alt kısmına, yani en çok oy veren kesime, fayda sağlamıştır. Artan oranlılık ile elde edilen tek sonuç toplumun en başarılı üyelerinin gelirlerinde büyük bir kısıtlama meydana gelmesidir. Ayrıca Hayek tarihsel olarak incelendiğinde artan oranlılığın üst sinıftan değil, orta sinıftan finanse edilen alt sinıfın gelirinin arttığını ileri sürmektedir (Hayek, 1960, s. 313-314).

Hayek ayrıca artan oranlılı̆̆ı desteklemek için kullanılan, daha yüksek gelire sahip olanların daha yüksek vergilere tabi olmasını öneren "eşit fedakarlık" argümanına da şüphe ile yaklaşmaktadır. İnsanların gelirlerinin bir kısmından vazgeçtikleri zaman yaptıkları fedakarlığı kıyaslamak ve yine farklı insanlar arasında karşılaştırma veya ölçüm yapmak temelde sübjektif nitelik taşıdığı için mümkün değildir. Ek olarak, bir kimsenin geliri artarken, kişiyi ekstra çalışmaya yönlendirmek, ücretine ilave yapılmasını gerektirmektedir. Ancak bu artan oranlılığın mevcut olması durumunda, artan oranlının lehine bir durum değildir (Butler, 2001, s. 153-154). Hayek ayrıca değer kavramına dayalı vergi analiz yöntemlerinin zayıflığından ve faydanın ölçülmesi ve karşılaştırılması bakımından yaşanan zorluklardan da bahsetmektedir (Estrada, 2010).

Hayek (1960) ayrica artan oranlı vergilendirme meselesinin bir ahlaki boyutunun da olduğunu ifade etmekte ve şu soruyu sormaktadır: “...acaba insanlar artan oranlılık ilkesinin nasıl işlediğini tam olarak anlasaydı bu ilkenin benimsenmesinde israr ederler miydi?". Artan oranlılık ilkesinin benimsenmesi neticesinde; ortaya çıkan belirli bir çoğunluğun bir azınlık üzerine ayrımcı nitelikte bir vergi yükü getirmesi, kimi zaman eşit işlerin farklı vergilendirilmesi, işçi sınıfı için sadece gelirleri geri kalanlarla aynı düzeyde değil diye olan teşviklerin fiilen etkisiz hale getirilmesi gibi sonuçların ahlakilik durumu tartışmalıdır.

Hayek'e (1960) göre eğer uygulanabilir ve ideal bir vergilendirme sistemini hayata geçirmek istiyorsak şu ilkeyi benimsemeliyiz: "Toplam vergi miktarının ne olacağına karar veren çoğunluğun, karşılık olarak bu verginin maksimum oranına katlanması gerekmektedir." Hayek, artan oranlı vergilendirmenin benimsenmesi durumunda, oranların keyfi bir şekilde belirlenmesini önleyecek bir ilkenin var olmayışından sıklıkla bahsetmektedir. Ayrıca düşünür artan oranlılığa aşılmayacak bir üst sınırın koyulmasının hedeflenen amaca ulaşamayacağını ve bu üst sınırın ekstra gelir ihtiyacının ortaya çıkacağı durumlarda kolaylıkla değiştirileceğini ileri sürmektedir.

Hayek'e göre devletin temel görevi hukukun üstünlüğü ilkesini sağlayacak düzenlemeler yapmaktır. Bu sebeple devlet yasaların hâkimiyetini sağlayacak ve özgürlükleri tehditlere 
karşı koruyacak güce ve otoriteye sahip olmak mecburiyetindedir. Bu güçlü devlet hiçbir bakımdan, hiçbir nedenle kişisel özgürlükleri sınırlamamalı, aksine özgürlüklerin koruyucusu olmalıdır. Sosyal adalet talebi, gelirin yeniden dağıtımı, sosyal refah uygulamaları, sosyalizm ideali için yapılan müdahaleler meşru olarak kabul edilemez (Kalfa Ataay, 2016, s. 140).

\section{Sonuç}

Hayek'e göre insan aklının ve bilgisinin sınırları vardır. Bilgi toplum içinde bireyler arasında dağınık vaziyette bulunmaktadır. Tek bir zihin, toplumdaki tüm bilgiye sahip olamaz. Ekonomide yer alan aktörlerin zihinlerinde var olan tüm bilgiye sahip olamayacağımız için Hayek, güdülen müdahaleci politikalar sonucu ortaya çıkacak etkilerin belirsiz olacağını ifade etmektedir. Buradan hareketle, politika yapıcılar vergi politikalarını oluştururken ve uygularken, ekonomik düzen içindeki tüm bilgiye sahip olmayacakları gerçeğini göz önünde bulundurmalıdır.

Devletin zorlama gücünü kullanabilmesini meşrulaştıran durumlardan biri, üstlenmiş olduğu minimal görevleri yerine getirilmek için vergilere ihtiyaç duymasıdır. Vergilendirme, devletin zorlama gücünü kullanabileceği ender alanlardan biridir. Ancak devlet zorlama gücü vasıtasıyla bireylerden vergileri toplarken kendiliğinden doğan düzenin işleyişini ve adil davranış kurallarını gözetmelidir.

Hayek'e göre kanunlar, bireylerin faaliyetlerine bir sınırlama getirirken, hükümetlerin de hukukun üstünlüğü ilkesine bağlı kalmasını sağlamaktadır. Kurallar ve kanunlar açık ve önceden biliniyor olmalıdır. Dolayısıyla bireyler kendi çıkarlarını kolaylıkla takip edebilirler. Buradan hareketle, bireyler vergi ile ilgili ödevlerinden önceden haberdar olursa ve vergi sistemleri açık ve anlaşılabilir oluşturulursa bireyler hayatlarını sağlıklı bir şekilde idame ettirebilirler. Politika yapıcılar vergi politikalarını ve vergi sistemlerini oluştururken bu hususu göz önünde bulundurmalıdır.

Hayek artan oranlı vergilendirmenin bir yeniden dağıtım aracı olarak kullanılmasına şüphe ile bakmaktadır. Çünkü artan oranlılık yeniden dağıtım kapsamında düşük gelirli kesimlere yardım etmek yerine, işçi sınıfına ve orta sınıfın alt kısmına, yani en çok oy veren kesime, fayda sağlamıştır. Artan oranlılık ile elde edilen tek sonuç toplumun en başarılı üyelerinin gelirlerinde büyük bir kısıtlama meydana gelmesidir. Tarihsel süreçte incelendiğinde artan oranlılığın üst sınıftan değil, orta sınıftan finanse edilen alt sınıfın gelirinin arttığını görülmektedir. Hayek'e göre artan oranlı vergilendirme ayrımcılığa zemin hazırlamakta ve keyfiliği teşvik etmektedir. Artan oranlı vergilendirme hukukun üstünlüğü ve bireylerin yasalar önünde eşit muamele görme ilkesi ile çelişmektedir.

\section{Kaynakça}

Akıncı, M. (2017). Hayek'in Sosyal ve Siyasal Teorisi. Dumlupınar Üniversitesi Sosyal Bilimler Dergisi(39), 73-90.

Aktaş, S. (2018). Hayek'in Hukuk ve Adalet Teorisi. Ankara: Liberte Yayınları.

Butler, E. (2001). Hayek: Çă̆ımız İktisat ve Siyaset Felsefesine Katkısı. (Y. Z. Çelikkaya, Çev.) Ankara: Liberte Yayınları. 
Durmaz, N. (2015). Descartes'ta Yöntemin Kendisi ve Etkileri. Route Educational and Social Science Journal, 2(3), 118-129.

Erdoğan, M. (1993). Özgürlük, Adalet, Refah. Sosyopolitik Yaklaşım(1), 108-117.

Estrada, F. (2010). The Power to Tax: A Lecture of Hayek. Munich Personel RePEc Archive(MPRA Paper No: 31384).

Hayek, F. A. (1952). The Counter-Revolution of Science: Studies On The Abuse Of Reason. Glencoe: The Free Press.

Hayek, F. A. (1958). Individualism and Economic Order (Third Impression b.). Chicago: University Of Chicago Press.

Hayek, F. A. (1960). The Constitution of Liberty. London: Routledge \& Kegan Paul Ltd.

Hayek, F. A. (1966). The Principles of a Liberal Social Order. II Politico, 31(4), 601-618.

Hayek, F. A. (1978). Law, Legislation and Liberty, Volume 1: Rules and Order. Chicago: University of Chicago Press.

Hayek, F. A. (1979). Social Justice, Socialsim and Democracy. Australia: The Centre for Independent Studies.

Hayek, F. A. (1981). Law, Legislation and Liberty Volume 3: The Political Order of a Free People. Chicago: The University of Chicago Press.

Hayek, F. A. (1990). New Studies in Philosophy, Politics, Economics and The History of Ideas. London: Routledge.

Hayek, F. A. (1998). Law, Legislation and Liberty Volume 2: Mirage of Social Justice. London: Routledge.

Hayek, F. A. (2007). Road to Serfdom. Chicago: University of Chicago Press.

Kalfa Ataay, C. (2016). Hayek ve Friedman'ın Devlet Anlayışı. Marmara Üniversitesi Siyasal Bilimler Dergisi, 4(1), 129-151.

Kurt, S. (2006). Hayek'in Özgürlük ve Adalet Teorisi. ZKÜ Sosyal Bilimler Dergisi, 2(3), 199-213.

Smith, A. (2006). Milletlerin Zenginliği. (H. Derin, Çev.) İstanbul: Türkiye İş Bankası Kültür Yayınları.

Spicer, M. W. (1995). On Hayek and Taxation: Rationality, Rules, and Majority Rule. National Tax Journal, 48(1), 103-112.

Yayla, A. (1991). Adalet Teorilerine Genel Bir Bakış. Yeni Forum, 33-40.

Yayla, A. (2014). Özgürlük Yolu: Hayek'in Sosyal Teorisi. İstanbul: Profil Yayıncllık.

\section{Açıklamalar}

* Liberal felsefede yer alan adalet türleri prosedürel adalet, sosyal adalet ve faydacı adalet şeklinde sıralanabilir. Prosedürel adalet yalnızca bireylerin davranışlarını dikkate alan adalet türüdür. Hayek ve Nozick önemli temsilcileridir. İkinci Dünya Savaşı sonrası popülerliğini arttıran sosyal adalet, klasik hakların yetersiz kalması durumunda bu olumsuz durumun iyileştirilmesi için devlet müdahalesinin gerektiğini savunan adalet türüdür. Sosyal adalet, refah kavramı ile sıkı bir ilişki içerisindedir. Faydacı adalet ise adalet ve fayda arasında güçlü bir bağ kurmaktadır. Bu adalet türü, bireylerin faydalarının toplamının toplumsal faydayı oluşturabileceğini kabul ederken, bu durumun her zaman yeterli olmayacağını ifade etmektedir. Toplumsal faydayı garanti almak için de sosyallik iç güdüsünü ön plana çıkarır ve sosyal adalete ulaşır (Aktaş, 2018, s. 222-228). 